Service Learning at Community Colleges: Synthesis, Critique, and Recommendations for Future Research

Amanda Taggart

Mississippi State University

Gloria Crisp

The University of Texas at San Antonio 


\begin{abstract}
The purpose of this paper is to review and critique empirical work done, to date, specific to service learning experiences at the community college level. A review of the literature was conducted in order to examine the empirical work that has been developed regarding service learning, a form of experiential learning, at community colleges. The narrative defines service learning, describes types of service learning taking place on community college campuses, and synthesizes and critiques the service learning empirical work done to date. The review closes with specific recommendations for both researchers and practitioners regarding future research.
\end{abstract}

Keywords: service learning, experiential learning, community college, programs, student development 


\section{Service Learning at Community Colleges: Synthesis, Critique, and Recommendations for Future Research}

With the exception of the 2008 presidential election that saw the second-largest youth voter turnout in American history (Morgenstern, 2008), the American public has recently demonstrated a decline in civic and social participation. This decline has been shown to be particularly evident among college students (Hodge, Lewis, Kramer, \& Hughes, 2001). As such, civic engagement has reemerged as a central goal of higher education (Jones \& Abes, 2004), as evidenced by the growing number of college and university mission statements that emphasize the importance of developing good and moral citizens (Kezar, 2002). According to Kezar (2002), "Community service learning has burgeoned and captured the attention of educators, politicians, and students alike as a way to develop skills for democratic life" (p, 15). In turn, colleges and universities across the country have become increasingly engaged in efforts to provide students with opportunities to participate in some form of volunteer service (Astin, Sax, \& Avalos, 1999; Hodge et al., 2001).

Community colleges are in an ideal position to promote civic engagement, as their mission emphasizes the role of the institution in serving the community (Hodge et al., 2001). The challenge, however, lies with finding ways to engage community college students in volunteer or civic related activities, as this unique group of students typically has fewer opportunities to engage with faculty and peers or participate in social and academic activities outside of the classroom (Bailey \& Alfonso, 2005; Cohen \& Brawer, 2003; McIntosh \& Rouse, 2009). As such, the classroom experience must be strategically designed to promote meaningful learning experiences for community college students (Bailey \& Alfonso, 2005; Barnett, 1996; Duffy, Franco, Hendricks, Henry, Baratain, \& Renner, 2007; Franco, 2009; Robinson, 2004). One 
strategy often employed to reach this goal is service learning, a unique form of experiential education (Berson \& Younkin, 1998).

Service learning can be defined as "a teaching and learning strategy that integrates meaningful community service with instruction and reflection to enrich the learning experience, teach civic responsibility, and strengthen communities" (National Service-Learning Clearinghouse, 2009). Although the term service learning has been used to refer to a wide range of activities, including volunteer work and community service (Robinson, 2004; Robinson \& Barnett, 1996) or internships and work-study positions (Lester \& Robinson, 2007), service learning is typically structured as part of a credit-bearing course that requires students to participate in organized service to the community (e.g., Robinson \& Barnett, 1996). More specifically, service learning programs commonly include a requirement of around 20 hours of community service in conjunction with an academic course (Berson \& Younkin, 1998; Cram, 1998; Haines, 2002). Furthermore, some service learning courses typically mandate active and guided reflection as part of the volunteer service required in the course (Exley, 1996; Largent \& Horinek, 2008). The use of service learning within the context of developing college students' moral development and social and academic involvement is supported by numerous higher education theories, including Astin's Theory of Student Development (1984), Tinto's Model of Student Integration (1975; 1993), and Kohlberg's Theory of Moral Development (1984).

One prominent national service learning project is the American Association of Community Colleges (AACC) Broadening Horizons through Service Learning project, whose goal is to integrate service learning into the institutional climate of community colleges and to increase the number, quality, and sustainability of service learning programs in higher education (American Association of Community Colleges, n.d.). Similarly, Campus Compact is a national 
organization that has brought more than 570 college presidents to the idea that service should be a primary component of their institutional agendas. Moreover, support for community colleges engaged in service learning is provided through the AACC, which has a clearinghouse to assist more than 650 community colleges by providing program-related announcements and publications (AACC, 1998).

A growing body of research demonstrates the relationship between participation in service learning and engagement in student learning. Engagement in learning improves academic outcomes (e.g., Berson \& Younkin, 1998) and leads students to become active citizens (e.g., Prentice, 2009). However, the majority of research to date has been conducted specific to students attending four-year institutions (e.g., Amtmann, Evans, \& Powers, 2002; Einfeld \& Collins, 2008; Hollis, 2002; Shiarella, McCarthy, \& Tucker, 2000). Research focusing specifically on four-year institutions is problematic as there is a wealth of empirical support for the assertion that a community college setting uniquely impacts student outcomes such as persistence (e.g., Pascarella, 1999; Pierson, Wolniak, Pascarella, \& Flowers, 2003). As such, it is not appropriate to assume that a service learning experience will impact students attending twoyear colleges and four-year institutions in the same ways. Rather, methodologically sound empirical work done with community college samples is required to establish the relationship between service learning and outcomes for community college students.

There is a need for synthesis, critique, and dissemination of programmatic efforts at community colleges to assist both faculty and practitioners involved in efforts to promote civic and social participation (Kozeracki, 2000). Despite calls from researchers for critical analyses of 
service learning programs, with the exception of descriptions of service learning programs offered by Prentice (2000) and Kozeracki (2000), as well as suggestions for establishing service learning programs provided by Peterman (2000), there has been little formal analysis of service learning programs at the community college level.

To date, there have been narrative reviews conducted specific to service learning programs at the K-12 level (e.g., Johnson \& Notah, 1999) as well as broad overviews of service learning in higher education. For example, a narrative review that included both two- and fouryear institutions by Giles and Eyler (1998) provides a synthesis of service learning research in higher education. Their work contributes to the literature by providing a synthesis of the benefits of service learning as well as an agenda for service learning research, but is limited in that it does not exclusively focus on nor compare work done at the community college level.

Similarly, Eyler, Giles, Stenson, and Gray (2001) conducted a comprehensive summary of findings of service learning research at both two- and four-year institutions. In line with their earlier work, the review suggests that service learning has a positive impact on numerous personal, social, learning, career, institutional, and faculty outcomes. The exception is reviewed studies examining grade point average (GPA), course grades, and cognitive moral development, which have indicated both positive and negative findings. Unfortunately, the synthesis provided by Eyler et al. (2001) did not provide an examination or critique of the methodology, sample, or analysis of previous work. As such, it is difficult to assess the quality and focus of the literature, including identifying and comparing studies that included community college students.

In turn, the purpose of the current narrative is to review and critique empirical work done to date specific to service learning experiences at the community college level. The following review consists of five sections. First, we outline the methodological and other criteria used for 
inclusion in the narrative review. Second, we describe and synthesize empirical work on service learning at community colleges. Third, we detail the programmatic outcomes identified in the reviewed empirical studies. Fourth, we provide a critique of the empirical work on service learning. Finally, we offer recommendations for both future research and practice, as our intended audiences include academic researchers, community college faculty, and student affairs practitioners and administrators.

\section{Method}

\section{Inclusion/Exclusion Criteria}

The following criteria were used to identify studies on service learning to be included in the synthesis and critique sections. First, the included studies all involved empirical research on or evaluation of service learning programs and experiences. Descriptions of programs, existing narrative reviews, and theoretical or opinion pieces were used to structure the introduction but were not included in the research synthesis section. Second, studies had to be concerned with programs at the community college level. Empirical studies conducted at the K-12 level or at four-year institutions were excluded. Third, studies had to explore the impact of the program/experience on students. Studies that focused on other samples, such as faculty members, were excluded. Fourth, studies that were incorporated into the review did not have to be published. However, they had to be publicly accessible or archived in summer 2009. Finally, included studies could be conducted in the United States or overseas, but must have been published in English.

\section{Search Procedures}


Within the boundaries mentioned above and as part of a larger narrative review process, we searched journal articles, conference presentations, dissertations, unpublished policy reports, and book chapters. We also conducted electronic searches via the following databases: Education Full Text, ERIC via EBSCO, JSTOR, and Project Muse. Next, we completed manual searches in 39 journals, including the top tier higher education journals and those specific to experiential learning, community colleges, evaluation, or student affairs (e.g., Journal of College Student Development, NASPA Journal, Journal of Experiential Education, Journal of College Orientation and Transition, Journal of the Freshman Year Experience, Community College Review). Search terms included different combinations of the following key words: "programs," "student development," "community college," "service learning," "experiential learning," and "student success."

Due to the scarcity of published empirical studies, the review was extended to books and unpublished manuscripts from policy centers and other groups focused on student success among community college students (e.g., How College Affects Students, Student Success in College: Creating Conditions that Matter). Additionally, websites from 29 organizations and centers that were known to concentrate efforts and/or conduct research on student success (e.g., Community College Research Center (CCRC), MDRC, and the Lumina Foundation) were also searched (see Appendix A). The reference lists of identified books, narrative reviews, and empirical studies were also reviewed for potential inclusions.

\section{Results}

\section{Description of Empirical Studies}


In total, we reviewed 17 empirical studies on service learning at community colleges (studies are highlighted in the reference list). Of these, the majority of studies (59\%) were published in journal articles, five (29\%) were dissertations or theses, one (6\%) was a conference presentation, and one (6\%) was a book chapter. Eight studies (47\%) utilized quantitative methods, five (29\%) used qualitative methods, and the remaining four studies $(24 \%)$ used a mixed methods approach. The most common data collection tools were questionnaires and interviews, though secondary data analysis, multiple choice tests, observations, and document analysis were also utilized.

Community college students were used as participants in all of the reviewed studies. However, faculty members' opinions were also used in several studies as a means to triangulate students' perceptions (e.g., Berson \& Younkin, 1998; Reed \& Pietrovito, 2000; Weglarz \& Seybert, 2004). Courses that utilized service learning covered a wide range of content areas, with health sciences, communications, English, sociology, and psychology courses being the most frequently used. The service learning experience was also examined within the context of several specific student populations such as English language learners and developmental students (i.e., Elwell \& Bean, 2001; Prentice, 2009). It is also noteworthy that service learning was operationalized or measured in different ways across the reviewed studies (e.g., 20-hour extracurricular experience, working with an aging population).

\section{Programmatic Outcomes}

Within the context of a community college setting, researchers have found generally positive outcomes for participation in service learning. The following section synthesizes these outcomes (see Appendix B). 
Student success. Four of the reviewed studies examined the impact or relationship between participation in service learning and student success as measured by course completion, grades, or students' decisions to persist. For instance, results of a quasi-experimental study involving 286 students enrolled in six paired community college courses in history, sociology, and English classes found that service learning activities were associated with higher final course grades as well as more stimulating class discussions (Berson \& Younkin, 1998). Similarly, Hollis (2002) utilized a quasi-experimental design to compare reflective essays and test scores of two comparable sociology courses (i.e., experimental and treatment groups). Among other findings, Hollis (2002) found that students in the service learning class earned higher grades.

Moreover, findings by Hodge et al. (2001) indicated that participation in service learning was positively related to student retention. Although the study used longitudinal data to support the validity of the findings, it should be noted that the design utilized by the researchers involved an examination of multiple treatments (i.e., combination of service learning activities in a learning community setting) in multiple courses that had different service learning requirements. As such, it is not entirely clear if students' experiences with service learning were solely responsible for higher retention rates or whether participants were more likely to be retained due to a combination of service learning and the supportive learning environment provided by a learning community.

In contrast, mixed findings were found by Prentice (2009), who compared student outcomes in eight sections of a developmental reading and writing and student life skills course that contained a service learning component with outcomes in eight comparable courses that did not contain a service learning component. Findings indicated that students enrolled in the courses that utilized service learning were less likely to earn a satisfactory grade than students enrolled in 
non-service learning sections. However, retention to subsequent semesters was found to be higher for students who were provided a service learning experience (Prentice, 2009).

Attitudes/perceived personal benefits. Many of the reviewed studies examined students' attitudes about civic involvement (e.g., understanding democratic ideals, social linkages to poverty, awareness of community needs) and/or perceived personal benefits to participating in service learning (e.g., sense of personal or moral growth, gains in interpersonal skills or selfesteem). Overall, findings were positive, indicating a positive relationship between students' attitudes with civic involvement and/or positive student perceptions of the experience (e.g., Eklund-Leen, 1994; Exley, 1996; Gutheil, Chernesky, \& Sherratt, 2006; Hodge et aI., 2001; Hollis, 2002; Hughes, 2002; Prentice, 2007; Prentice, 2009; Weglarz \& Seybert, 2004).

For instance, a grounded theory investigation by Hughes (2002) involving interviews with 24 students at Virginia Highland and Mountain Empire Community Colleges found that participation in service learning was perceived by participants to lead to benefits in civic responsibility, civic mindedness and community building, personal efficacy, developing a meaningful philosophy on life, appreciation for diversity, and altruism. Similarly, although the study design did not utilize a control or comparison group, observations, interviews and questionnaires collected and analyzed by Elwell and Bean (2001) revealed that students benefitted from the infusion of service learning into the course curriculum. Moreover, qualitative findings involving 11 women enrolled in a course on aging suggest that participation in a service learning experience improved students' attitudes toward older adults as well as increased their interest in working with older adults in the future (Gutheil, Chernesky, \& Sherratt, 2006).

The only reviewed study that failed to find gains in students' attitudes toward civic engagement or personal outcomes was a dissertation by Cram (1998). The study utilized a quasi- 
experimental design to compare students' scores on the defining issues test (DIT) and the self esteem questionnaire (SEQ-3) among students enrolled in a section of an ethics course that included a service learning component with two sections that did not involve service learning. In contrast to the other reviewed studies, the researcher found no statistical evidence to support growth of self-esteem or significant moral growth among students who did and did not engage in a service learning experience.

Participants' satisfaction. In regard to satisfaction with a service learning experience, many studies have identified positive feelings toward participation in service learning programs (e.g., Amtmann et al., 2000; Berson \& Younkin, 1998; Elwell \& Bean, 2001; Exley, 1996; Largent \& Horinek, 2008; Reed \& Pietrovieto, 2000; Weglarz \& Seybert, 2004). In particular, Berson and Younkin (1998) found that students who participated in a section of a history, sociology, or English course that incorporated a service learning experience reported higher overall satisfaction with the course when compared to students who enrolled in classes without a service learning requirement. In addition, findings of program evaluations at Mount Wachusett Community College and Johnson County Community College both revealed that service learning program participants were satisfied and felt that the programs had merit and worth (Reed \& Pietrovito, 2000; Weglarz \& Seybert, 2004). Similarly, data collected by Largent and Horinek (2008) indicated that students enrolled in nursing, humanities, communications, and occupational therapist assistant courses were satisfied with the service learning program. However, older students, defined as students older than 23 years of age, were found to be less satisfied than traditional aged students. Interviews with older students were conducted to investigate the causes for their lower levels of satisfaction with the program, and responses revealed that older students desired service learning assignments that were clearly meaningful and that connected their prior 
knowledge to activities.

Application of knowledge. The value of service learning programs in the application of course knowledge was examined in three of the reviewed studies. The first, a case study by Amtmann et al. (2000), revealed the importance of service learning to students' ability to apply what they learned in their classes, as community college students in a health program were required to participate in service learning via work with a prison wellness program, giving them both challenging and practical work experience. Similarly, faculty-reported data as part of a program evaluation by Reed and Pietrovito (2000) suggested that service learning allowed participants to apply the course material and provided an opportunity for real learning about work and life. Moreover, qualitative findings by Hughes (2002) indicated that many service learning participants emphasized the benefits of "hands-on experience" provided by service learning activities.

Program challenges. Finally, several of the reviewed studies examined challenges to implementing service learning on a community college campus (i.e., Hughes, 2002; Largent \& Horinek, 2008; Reed \& Pietrovito, 2000; Ward, 1996). Findings indicated that both students and faculty identified finding time for the additional work as a major challenge to service learning (Hughes, 2002; Largent \& Horinek, 2008; Prentice, 2009; Reed \& Pietrovieto, 2000). Other challenges included multiple competing priorities, such as job and family responsibilities (Hughes, 2002; Largent \& Horinek, 2008). Moreover, a case study on institutional support for service learning at a tribally controlled community college and three four-year institutions also identified funding as a frequent barrier to the implementation of effective service learning (Ward, 1996).

\section{Critique of Service Learning Studies}


We noted numerous methodological strengths across the reviewed studies focused on service learning programs at community colleges. For instance, several of the reviewed studies were theoretically grounded (e.g., Eklund-Leen, 1994), which allowed the researchers to understand the findings within the broader context of the higher education literature. Second, although few studies utilized experimental designs to measure the causal effect of service learning (Smith, 2008), several of the reviewed studies utilized well-designed quasi-experimental designs that made attempts to control for extraneous variables and/or included a comparable control group (e.g., Berson \& Younkin, 1998; Cram, 1998; Hollis, 2002). Third, we observed that many of the studies that utilized a qualitative or mixed methods design used one or more forms of triangulation (i.e., data, method, investigator) in an effort to promote validity (e.g., Burr, 1999; Elwell \& Bean, 20Gl;Gutheil, Chernesky, \& Sherratt, 2006). Finally, several of the reviewed studies provided a detailed description of the program to allow future researchers the ability to replicate the implementation of the service learning activities/experience (e.g., Cram, 1998; Prentice, 2009).

We also observed several weaknesses in the reviewed studies. For example, like Kozeracki (2000), we determined that much of the service learning literature is descriptive, focusing on the structure of and participation in service learning programs rather than measuring the impact of service learning on student success. In addition, the majority of measured outcomes were self-reported, focusing on participants' perceptions rather than measuring observed benefits to participation in service learning activities (e.g., increases in the frequency of civic involvement behavior). Similarly, the focus of many of the studies to date has been program evaluation, which in tum has influenced the outcomes of interest toward program satisfaction or merit and worth rather than measuring the influence of programs on student success and/or civic 
involvement. We also noted that the majority of studies were conducted by community college faculty or staff, which may have biased the data collection or findings (e.g., students may have told the professor that they were satisfied and/or learned from the program in order to earn a good grade).

Additionally, the majority of reviewed work was limited to samples at a single community college, or in many cases, one or a few classes within a single college. As such, the generalizability of the findings to other institutional types and student groups is not known. The limitations with regard to external validity are especially noteworthy given the heterogeneity of student samples used (e.g., ESL students, developmental students, students enrolled in non-core courses such as architecture) as well as the lack of consistency in program design and implementation in the studies that were reviewed. Moreover, we observed that several of the reviewed studies (e.g., Gutheil, Chernesky, \& Sherratt, 2006; Hodge et al., 2001) failed to utilize multivariate analyses such as ordinary least squares (OLS) or binary logistic regression, thereby limiting the ability to control for confounding variables.

Furthermore, many times more than one intervention was being measured simultaneously, such as work by Hodge et al. (2001), who, as previously mentioned, concurrently measured both service learning and learning communities. Within the studies reviewed, neither the definition nor measurement of service learning was consistent. In some studies, for example, researchers defined service learning as an extracurricular, or out-of-class, experience (i.e., Amtmann et al., 2000), while others examined service learning experiences within the context of academic courses (i.e., Berson \& Younkin, 1998; Burr, 1999; Cram, 1998; Haines, 2002; Largent \& Horinek, 2008). Of the studies examining service learning as part of an academic course, service learning was examined both as a required part of course 
curriculum (i.e., Cram, 1998; Haines, 2002; Largent \& Horinek, 2008) and as an optional component of the course (i.e., Hollis, 2002).

In addition, although some of the studies made reference to relevant theoretical frameworks (e.g., Berson \& Younkin, 1998; Cram, 1998; Eklund-Leen, 1994; Hughes, 2002), it was often unclear how theory was connected to the development and/or measurement of service learning programs. In turn, the service learning experience itself was implemented and/or measured differently across studies. For example, several studies examined courses where 20 hours of service learning were required in addition to regular course curriculum (i.e., Berson \& Younkin, 1998; Cram, 1998; Haines, 2002). However, other studies examined courses that treated service learning as whole-class projects integrated into a course theme (i.e., Hodge et al., 2001). For instance, one instructor, as part of her teaching of the novel Of Mice and Men, organized a supply drive to help migrant workers suffering from a destructive weather freeze (Elwell \& Bean, 2001).

\section{Recommendations for Research and Practice}

In response to the above-mentioned weaknesses of the reviewed empirical work, we offer several recommendations to advance the literature specific to service learning at community colleges. First and foremost, there is a need for research that is able to substantiate the causal link between service learning and various student outcomes (Berson \& Younkin, 1998). As such, we recommend that more research be conducted with the focus of isolating the effect of service learning programs on traditional measures of student success (e.g., academic achievement, persistence). More specifically, we recommend that researchers extend the use of experimental or quasi-experimental designs that include a control group and are able to properly control for selection bias. Although these types of designs add to the complexity of conducting research on a 
community college campus, the use of experimental and/or quasi-experimental designs necessarily addresses issues of internal validity by properly isolating or controlling for possible confounding variables.

Second, there is a need for future research to address the issue of external validity, or the generalizability of findings, across different institutional types and student groups. For instance, while prior research on student success suggests that the impact of service learning might be different for students at two- and four-year institutions, at this time we do not understand how service learning programs vary across institutional types (Kozeracki, 2000). As such, researchers should attempt to replicate well-designed studies conducted on four-year institutions (e.g., Einfeld \& Collins, 2008) in an effort to assess the variability of programmatic outcomes across institutional types. Additionally, because community college students are so diverse, there is also a need to better understand how service learning impacts different groups of students. For example, findings by Largent and Horinek (2008) suggest that older students may be less satisfied with a service learning experience than younger students. Similarly, findings by Prentice (2009) suggest that service learning may have a different effect on students enrolled in developmental courses. Moreover, researchers should consider investigating the impact of experiences on student sub-populations previously found to experience community college differently (e.g., full- and part-time students).

Third, there is a need to better connect relevant student development and psychological theory (i.e., Astin, 1984; Kohlberg, 1958, 1984; Tinto, 1993) to the design and assessment of service learning programs. For example, a service learning project developed within the context of a philosophy course may involve activities specifically designed to facilitate community college students' transition from the conventional to post-conventional stage of morality as 
theorized by Kohlberg's (1958) theory of moral development (e.g., volunteering as a child advocate). In this case, the research design may involve control and experimental groups either randomly assigned or matched to be equivalent. The assessment of programmatic outcomes could include the comparison of pre and post measures of moral development using a previously validated scale.

Fourth, there is a need for studies that examine the long-term effects of service learning on civic involvement (Kozeracki, 2000). Similarly, the findings from this review substantiate both Cram (1998) and Smith's (2008) call from more than a decade ago for work that examines the relationship between the developmental impacts of service learning. Moreover, it would be beneficial to conduct more studies that examine the effect of service learning models on students' mastery of discipline-specific course material (Hollis, 2002). Furthermore, there have been few attempts to establish the conditions under which service learning is most effective (Hughes, 2002). As such, we recommend that additional empirical work be conducted specific to this purpose.

Both community college faculty and practitioners who engage in service learning program evaluation should be encouraged to present their findings at conferences and publish their research in journals. It is assumed that well-designed evaluations and/or action research studies that could be presented at conferences are not often presented or published in mainstream journals, such as the work of Berson and Younkin (1998) that studied the effects of service learning at six community colleges. As Elwell and Bean (2001) suggest, programs that incorporate service learning offer community college faculty the opportunity to conduct research that directly connects and adds to their teaching. Therefore, community colleges should 
encourage and support the development and dissemination of service learning research on their campuses.

We acknowledge that researchers, faculty, and staff desiring to conduct service learning research/evaluation may face a variety of obstacles when attempting to address the abovementioned methodological limitations. Namely, resources (e.g., time, financial support, methodological expertise) needed to utilize experimental or longitudinal designs, build in necessary controls, and/or perform inferential analyses are often not available to researchers, community college faculty, and/or student affairs practitioners at the community college level. It has been suggested that service learning is one of the best ways for academic and student affairs professionals to collaborate (Berson \& Younkin, 1998). Therefore, we strongly recommend that faculty and staff explore creative ways to combine resources and expertise when collecting, analyzing, and disseminating research on service learning. Moreover, we recommend that researchers, faculty, and staff seek external funding support in an effort to produce and disseminate the most methodologically sound research possible. 


\section{References}

American Association of Community Colleges, (1998). Service learning and community colleges: Building a national network. Final progress report. Washington, DC. Retrieved from ERIC database. (ED455899)

*Amtmann, J., Evans, R., \& Powers, J. (2002). Case study of a service-learning partnership: Montana Tech and the Montana State Prison. JCE, 53(1), 23-27.

Astin, A. W (1984). Student involvement: A developmental theory for higher education. Journal of College Student Personnel, 25, 297-808.

Astin, A. W, Sax, L. J., \& Avalos, J. (1999). Long-term effects of volunteerism during the undergraduate years. The Review of Higher Education, 22(2), 187-202.

Bailey, T. R., \& Alfonso, M. (2005). Paths to persistence: An analysis of research on program effectiveness at community colleges. Lumina Foundation for Education New Agenda Series, 6(1). Indianapolis, IN: Lumina Foundation for Education.

Barnett, L. (1996). Service learning: Why community colleges? New Directions for Community Colleges, 93, 7-15.

*Berson, J. S., \& Younkin, W F. (1998). Doing well by doing good: A study of the effects of a service-learning experience on student success. Paper presented at the 23rd Annual Meeting of the Association for the Study of Higher Education, Miami, FL. Retrieved from Eric database. (ED427568)

*Burr, K. (1999). Problems, politics, and possibilities of a progressive approach to service learning in a community college: A case study. Journal of Industrial Teacher Education, $36(3), 1-21$. 
Cohen, A. M., \& Brawer, F. B. (2003). The American community college. San Francisco, CA: Jossey-Bass.

*Cram, S. B. (1998). The impact of service-learning on moral development and self-esteem of community college ethics students (Doctoral dissertation). Available from Dissertation Abstracts International. (UMI No. 9834451)

Duffy, D., Franco, R, Hendricks, A, Henry, R, Baratian, M., \& Renner, T. (2007). Servicelearning course design for community colleges. Boston, MA: Campus Compact.

Einfeld, A, \& Collins, D. (2008). The relationships between service-learning, social justice, multicultural competence, and civic engagement. Journal of College Student Development, 49(2), 95-109.

*Eklund-Leen, S. J. (1994). A study of the relationship of student co-curricular activity, intensity of involvement and other selected variables to attitude and estimated behavior toward community involvement among community college students (Doctoral dissertation). Available from Dissertation Abstracts International. (UMI No. 9534477)

*Elwell, M. D., \& Bean, M. S. (20m). Editor's choice: The efficacy of service-learning for community college ESL students. Community College Review, 28(4), 47-61.

*Exley, R. J. (1996). Commitment to community: Service learning at Miami Dade Community College. New Directions for Community Colleges, 93, 35-42.

Eyler, J. S., Giles, D. E., Jr., Stenson, C. H., \& Gray, C. J. (2001). At a glance: What we know about the effects of service-learning on college students, faculty, institutions and communities, 1993-2000 (3rd ed.). Funded by the corporation for National Service Learn and Serve American National Service Learning Clearinghouse. Retrieved from the 
National Service Learning Clearinghouse website:

http://www.servicelearning.org/pubs/materials/L054

Franco, R. W. (2009). Service-learning: Reconciling research and teaching, tackling capacious issues. Campus Compact. Retrieved from the Campus Compact web site: http://www.compact.org

Giles, D. E., \& Eyler, J. S. (1998). A service-learning research agenda for the next five years. In R. Rhoads \& J. Howard (Eds.), Academic service-learning: A pedagogy of action and reflection (pp. 65-72). San Francisco, CA: Jossey-Bass.

*Gutheil, 1. A, Chernesky, R. H., \& Sherratt, M. L. (2006). Influencing student attitudes toward older adults: Results of a service-learning collaboration. Educational Gerontology, 32, $771-784$

*Haines, D. L. (2002). A study of community college attitudes related to service learning (Doctoral dissertation, Baylor University). Retrieved from Eric database. (ED479826)

*Hodge, G., Lewis, T., Kramer, K., \& Hughes, R. (2001). Collaboration for excellence: Engaged scholarship at Collin County Community College. Community College Journal of Research and Practice, 25, 675-690.

*Hollis, S. A. (2002). Capturing the experience: Transforming community service into service learning. Teaching Sociology, 30(2), 200-213.

*Hughes, A. (2002). A study of service-learning at Virginia Highlands Community College and Mountain Empire Community College (Doctoral dissertation). Available from Dissertation Abstracts International. (UMI No. 3042420)

Johnson, A. M., \& Notah, D. J. (1999). Service learning: History, literature review, and a pilot student of eighth grade students. The Elementary School Journal, 99(5), 453-467. 
Jones, S. R., \& Abes, E. S. (2004). Enduring influences of service-learning on college students' identity development. Journal of College Student Development, 45(2), 149-166.

Kezar, A. (2002). Assessing community service learning: Are we identifying the right outcomes? About Campus, 7(2), 14-20.

Kohlberg, L. (1958). The development of modes of moral thinking and choice in the years 10 to 16. (Unpublished doctoral dissertation), University of Chicago, Chicago, IL.

Kohlberg, L. (1984). The philosophy of moral development moral stages and the idea of justice. Cambridge, MA: Harper \& Row.

Kozeracki, C. A. (2000). ERIC review: Service learning in the community college. Community College Review, 27(4), 54-70.

*Largent, L., \& Horinek, J. B. (2008). Community colleges and adult service learners: Evaluating a first-year program to improve implementation. New Directions for Adult and Continuing Education, 118, 37-47.

Lester, C., \& Robinson, G. (Eds.). (2007). An American mosaic: Service learning stories. Washington, D.C.: American Association of Community Colleges.

McIntosh, M. F., \& Rouse, C. E. (2009). The other college: Retention and completion rates among two-year college students. Washington, D.C.: Center for American Progress. Morgenstern, C. (2008, November 10). Election 2008: Second-largest youth voter turnout in American history. The Tartan. Retrieved from http://thetartan.org/2008/11/10/news/elections

National Service Learning Clearinghouse. (2009). What is Service-Learning? Retrieved from http://www.servicelearning.org/what-service-learning 
Nora, A. (1987). Determinants of retention among Chicano college students. Research in Higher Education, 26(1), 31-59.

Pascarella, E. (1999). New studies track community college effects on students. Community College Journal, 69, 9-14.

Peterman, D. (2000). Service learning in community colleges. Community College Journal of Research and Practice, 24, 321-325.

Pierson, C. R., Wolniak, G. C., Pascarella, E. T., \& Flowers, L. A. (2003). Impact of two-year and four-year college attendance on learning orientations. Review of Higher Education, 26(3), 299-321.

Prentice, M. (2000). Service learning programs on community college campuses. ERIC Clearinghouse for Community Colleges, Los Angeles, CA. Retrieved from ERIC database. (ED451857)

*Prentice, M. (2007). Social justice through service learning: Community colleges as ground zero. Equity and Excellence in Education, 40(3), 266-273.

*Prentice, M. (2009). Service-learning's impact on developmental reading/writing and student life skills courses. Community College Journal of Research and Practice, 33(3), 270-282.

*Reed, C. B., \& Pietrovito, J. A. (2000). Evaluation of the service learning program at Mount Wachusett Community College. History, philosophy, and practices of adult education. (Ed. D. Practicum paper). Nova Southeastern University, Fort Lauderdale, FL. Retrieved from ERIC database. (ED482717)

Robinson, G. (2004). Community colleges broadening horizons through service learning, 20032006. American Association of Community Colleges. 
Robinson, G., \& Barnett, L. (1996). Service learning and community colleges: Where we are. AACC Survey Report. AACC, Washington, D.C. Retrieved from ERIC database. (ED394612)

Shiarella, A. H., McCarthy, A. M., \& Tucker, M. L. (2000). Development and construct validity of scores on the community service attitudes scale. Educational and Psychological Measurement, 60(2), 286-300.

Smith, M. C. (2008). Does service learning promote adult development? Theoretical perspectives and directions for research. New Directions for Adult and Continuing Education, 118, 515.

Tinto, V. (1975). Dropout from higher education: A theoretical synthesis of recent research. Review of Educational Research, 45, 89-125.

Tinto, V. (1993). Leaving college' Rethinking the causes and cures of student attrition. Chicago, IL: University of Chicago Press.

Ward, K. (1996, April). Service learning and student volunteerism: Reflections on institutional commitment. Paper presented at the Annual Meeting of the American Educational Research Association, New York, NY.

*Weglarz, S. G., \& Seybert, J. A. (2004). Participant perceptions of a community college service-learning program. Community College Journal of Research and Practice, 28, 123-132.

*Included in narrative review 


\section{Appendix A}

\section{Reviewed Organizations/Centers}

Achieving the Dream (http://www.achievingthedream.org/default.tp)

American Counseling Association (http://www.counseling.org/)

American Council on Education (http://www.acenet.edu/AM/)

American Diploma Project (http://www.achieve.org/ADPNetwork)

American Association of Community Colleges

(http://www2.aacc.nche.edu/research/index.htm)

Center for Research on Developmental Education and Urban Literacy (CRDEUL)

(http://www.cehd. umn.edu/CRDEULI)

Center for Student Success - California Community Colleges

(http://css.rpgroup.org/)

Center for the Study of College Student Retention (http://www.cscsr.org/)

Civil Rights Project (http://www.civilrightsproject.ucla.edu/)

Community College Research Center (CCRC) (http://ccrc.tc.columbia.edu/)

Council for Opportunity in Education (http://www.coenet.us/)

Council for the Advancement of Standards (https:/Iwww.cas.edu/index.html)

Education Commission of the States (http://www.ecs.org/)

Educational Policy Institute (http://www.educationalpolicy.org/)

Institute for Higher Education Policy (IHEP) (http://www.ihep.org/)

Lumina Foundation for Education (http://www.luminafoundation.org/)

MDRC (http://www.mdrc.org/)

National Academic Advising Association (http://www.nacada.ksu.edu/)

National Coalition Building Institute (http://ncbLorg/)

National Center for Postsecondary Improvement

(http://www.stanford.edulgroupincpi/)

National Center for Public Policy and Higher Education (NCPPHE)

(http://www.highereducation.org/)

National Resource Center for the Freshmen Year Experience

(http://www.sc.edu/fye/)

Pathways to College Network (http://www.pathwaystocollege.net/)

Policy Center on the First Year of College

(http://www.brevard.edu/Default.aspx?tabid=652)

The Puente Project (http://www.puente.net/)

State Policy Inventory Database Online (http://www2.wiche.edu/spido)

Student Affairs Administrators in Higher Education (NASPA)

(http://www.naspa.org/)

U.S. Department of Education (http://www.ed.gov/index.jhtml) 


\section{Appendix B}

\section{Summary of Reviewed Studies}

\begin{tabular}{|c|c|c|c|c|c|c|c|c|c|}
\hline & Method & Sample & $\begin{array}{c}\text { Data } \\
\text { Analysis }\end{array}$ & $\begin{array}{l}\text { Student } \\
\text { Success }\end{array}$ & $\begin{array}{c}\text { Attitudes/ } \\
\text { Perceived } \\
\text { Personal } \\
\text { Benefits } \\
\end{array}$ & Satisfaction & $\begin{array}{c}\text { App. of } \\
\text { Knowledge }\end{array}$ & $\begin{array}{c}\text { Program } \\
\text { Challenges }\end{array}$ & Other \\
\hline $\begin{array}{l}\text { Amtmann, } \\
\text { Evans, \& } \\
\text { Powers } \\
(2002)\end{array}$ & Qualitative & $\begin{array}{l}6 \text { college } \\
\text { students }\end{array}$ & $\begin{array}{l}\text { Identify } \\
\text { themes }\end{array}$ & & & $\mathrm{X}$ & $\mathrm{X}$ & & $\mathrm{X}$ \\
\hline $\begin{array}{l}\text { Berson \& } \\
\text { Younkin } \\
(1998)\end{array}$ & Quantitative & 286 students & $\begin{array}{c}\text { t-tests, } \\
\text { chi-square } \\
\text { tests }\end{array}$ & $\mathrm{X}$ & & $\mathrm{X}$ & & & \\
\hline Burr (1999) & Qualitative & 8 students & $\begin{array}{c}\text { Categorize } \\
\text { data }\end{array}$ & & $X$ & & & & $X$ \\
\hline Cram (1998) & Quantitative & $\begin{array}{l}32 \text { students } \\
\text { for one test, } \\
65 \text { students } \\
\text { for another } \\
\text { test }\end{array}$ & $\begin{array}{l}\text { Descriptive } \\
\text { statistics, } \\
\text { convergence } \\
\text { analysis, } \\
\text { linear } \\
\text { regression }\end{array}$ & & $\mathrm{X}$ & & & & \\
\hline $\begin{array}{l}\text { Eklund-Leen } \\
\text { (1994) }\end{array}$ & Quantitative & 177 students & $\begin{array}{c}\text { Descriptive } \\
\text { statistics }\end{array}$ & & $X$ & & & & \\
\hline $\begin{array}{l}\text { Elwell \& } \\
\text { Bean (2001) }\end{array}$ & Qualitative & 28 students & $\begin{array}{l}\text { Identify } \\
\text { themes }\end{array}$ & & & $\mathrm{X}$ & & & \\
\hline Exley (1996) & Quantitative & 428 students & $\begin{array}{c}\text { Descriptive } \\
\text { statistics }\end{array}$ & & $\mathrm{X}$ & $\mathrm{X}$ & & & $X$ \\
\hline $\begin{array}{l}\text { Gutheil, } \\
\text { Chernesky, } \\
\text { \& Sherratt } \\
(2006)\end{array}$ & Quantitative & $\begin{array}{l}9 \text { student } \\
\text { papers }\end{array}$ & $\begin{array}{l}\text { Content } \\
\text { analysis }\end{array}$ & & $\mathrm{X}$ & & & & \\
\hline $\begin{array}{l}\text { Haines } \\
\text { (2002) }\end{array}$ & Quantitative & 35 students & $\begin{array}{c}\text { Descriptive } \\
\text { statistics }\end{array}$ & & $\mathrm{X}$ & & & & \\
\hline Hollis (2002) & Qualitative & $\begin{array}{l}95 \text { students, } \\
\text { journals and } \\
\text { reflective } \\
\text { essays }\end{array}$ & $\begin{array}{l}\text { Inductive } \\
\text { content } \\
\text { analysis }\end{array}$ & $\mathrm{X}$ & $\mathrm{X}$ & & & & \\
\hline
\end{tabular}




\begin{tabular}{|c|c|c|c|c|c|c|c|c|}
\hline $\begin{array}{l}\text { Hughes } \\
(2002)\end{array}$ & Qualitative & 24 students & $\begin{array}{c}\text { Constant } \\
\text { comparative } \\
\text { method, } \\
\text { identify } \\
\text { themes }\end{array}$ & & $X$ & & $\mathrm{X}$ & $\mathrm{X}$ \\
\hline $\begin{array}{l}\text { Largent \& } \\
\text { Horinek } \\
(2008)\end{array}$ & $\begin{array}{l}\text { Mixed } \\
\text { Methods }\end{array}$ & $\begin{array}{l}475 \text { student } \\
\text { surveys, } 4 \\
\text { student } \\
\text { interviews } \\
\end{array}$ & ANOVA & & & $X$ & & $\mathrm{X}$ \\
\hline $\begin{array}{l}\text { Prentice } \\
\text { (2007) }\end{array}$ & Quantitative & $\begin{array}{c}42 \text { non- } \\
\text { service } \\
\text { learners and } \\
107 \text { service } \\
\text { learners from } \\
6 \text { colleges } \\
\end{array}$ & $\begin{array}{l}\text { Descriptive } \\
\text { statistics }\end{array}$ & & $\mathrm{X}$ & & & \\
\hline $\begin{array}{l}\text { Prentice } \\
(2009)\end{array}$ & Quantitative & 199 students & $\begin{array}{c}\text { Linear } \\
\text { regression, } \\
\text { descriptive } \\
\text { statistics } \\
\end{array}$ & $\mathrm{X}$ & $X$ & & & $X$ \\
\hline $\begin{array}{l}\text { Reed \& } \\
\text { Pietrovito } \\
\text { (2000) }\end{array}$ & Quantitative & $\begin{array}{c}20 \text { students, } \\
16 \text { faculty, } \\
20 \\
\text { community } \\
\text { partners }\end{array}$ & $\begin{array}{l}\text { Descriptive } \\
\text { statistics }\end{array}$ & & & $X$ & $X$ & $X$ \\
\hline $\begin{array}{l}\text { Weglarz \& } \\
\text { Seybert } \\
(2004)\end{array}$ & Quantitative & $\begin{array}{l}28 \text { faculty, } \\
204 \text { students }\end{array}$ & $\begin{array}{c}\text { Descriptive } \\
\text { statistics }\end{array}$ & & $X$ & $X$ & & \\
\hline
\end{tabular}

